\title{
Meningkatkan Karakter Anak Usia Dini melalui Pemberian Penguatan
}

\author{
Mukti Amini ${ }^{1 凶}$, Mariyati² $^{2}$ \\ Pendidikan Guru Pendidikan Anak Usia Dini, Universitas Terbuka \\ DOI: $10.31004 /$ obsesi.v5i2.1128
}

\begin{abstract}
Abstrak
Pengembangan karakter harus dilakukan sedini mungkin karena usia dini merupakan masa emas dalam pengembangan karakter. Salah satu teknik dalam peningkatan karakter adalah dengan pemberian penguatan. Penelitian ini bertujuan untuk meningkatkan karakter tanggung jawab anak melalui teknik pemberian penguatan baik secara verbal maupun nonverbal dengan cara pemberian pujian dan hadiah kepada anak. Metode yang digunakan adalah penelitian tindakan kelas menggunakan pola Kemmis \& Taggart dengan dua siklus. Subjek penelitian adalah 22 anak usia 5-6 di TK B TK Dharma Wanita I Pojoksari, Magetan, yaitu 12 anak laki-laki dan 10 anak perempuan. Hasil penelitian menunjukkan terdapat peningkatan karakter anak usia 5-6 tahun setelah mendapatkan penguatan dari guru. Performa karakter tanggung jawab anak meningkat sebesar $56,8 \%$ pada akhir siklus 1 dan $93,2 \%$ pada akhir siklus 2, dari data awal sebelum tindakan sebesar 37,5\%. Performa karakter bertangggung jawab ini ditunjukkan anak dalam empat aspek yaitu: mau mengambil alat main tanpa dibantu, melaksanakan tugas dengan gembira, menyelesaikan tugas yang diberikan guru, dan mengembalikan peralatan main ke tempatnya.
\end{abstract}

Kata Kunci: karakter; penguatan; anak usia dini.

\begin{abstract}
Character development must be done as early as possible because early age is a golden period in character development. One of the techniques in increasing character is by giving reinforcement. This study aims to improve the character of children's responsibility through verbal and nonverbal reinforcement techniques by giving praise and gifts to children. The method used was classroom action research using the Kemmis \& Taggart pattern with two cycles. The research subjects were 22 children aged 5-6 in group B, Dharma Wanita I Kindergarten, Pojoksari, Magetan, consisting of 12 boys and 10 girls. The results showed that there was an increase in the character of children aged 5-6 years after receiving reinforcement from the teacher. The children's responsibility character performance increased by $56.8 \%$ at the end of cycle 1 and $93.2 \%$ at the end of cycle 2, from the initial data before the action of $37.5 \%$. The performance of this responsible character is shown by children in four aspects, namely: willing to take the playing equipment without assistance, carry out tasks happily, complete the assignment given by the teacher, and return the play equipment to its place.
\end{abstract}

Keywords: character; reinforcement; early childhood

Copyright (c) 2021 Mukti Amini, Mariyati

$\triangle$ Correspondingauthor:

Email Address : muktiamini@gmail.com (Jakarta, Indonesia)

Received 4 February 2021, Accepted 15 February 2021, Published 25 February 2021 


\section{PENDAHULUAN}

Penanaman karakter harus dilakukan sejak anak usia dini, supaya karakter tersebut mengakar kuat pada diri anak hingga dewasa. Usia dini merupakan masa kritis bagi pembentukan karakter. Banyak pakar mengatakan bahwa kegagalan pengembangan karakter pada seseorang sejak usia dini akan membentuk pribadi yang bermasalah pada masa dewasanya (Allemand \& Hill, 2014). Lickona (dalam Megawangi, 2016) mengemukakan bahwa walaupun jumlah anak-anak hanya $25 \%$ dari total jumlah penduduk, tetapi menentukan $100 \%$ masa depan.

Pengembangan karakter bukan hanya masalah nilai moral, tetapi juga berkaitan dengan kesuksesan akademik anak. Selain kesuksesan akademik, pengembangan karakter juga berpengaruh pada perilaku sosial anak. Melalui karakter yang baik, anak mudah diterima oleh lingkungannya, sehingga suasana sekolah menjadi menyenangkan dan anak lebih siap untuk belajar. Hal ini berdampak pada kesuksesan akademiknya (Istiana, 2018; Maslan, 2019; Megawati \& Herdiyanto, 2016). Selain itu, anak-anak yang berkarakter baik adalah mereka yang mempunyai kematangan emosi dan spiritual tinggi, sehingga dapat mengelola stresnya dengan lebih baik, yang pada akhirnya dapat meningkatkan fisiknya (Bachri \& Suharnan, 2014).

Pengembangan karakter pada anak membutuhkan waktu yang tidak sebentar. Oleh karena itu dibutuhkan strategi yang tepat dan kesabaran dari para pendidik anak usia dini. Pendidik sebagai model bagi anak juga harus dapat memberi contoh yang baik kepada anak (Mitsansw, 2014). Menurut Lickona (dalam Hidayat, 2019) terdapat sebelas prinsip agar pengembangan karakter dapat berjalan efektif, salah satunya adalah upaya memotivasi anak. Nilai-nilai karakter juga dapat dikembangkan melalui pembiasaan rutin selama anak belajar di TK. Bahkan pembiasaan yang berkaitan dengan teknologi juga dapat diperkenalkan untuk mengembangkan karakter agar anak-anak tidak menyalahgunakan teknologi (Saptatiningsih \& Permana, 2019).

Salah satu cara yang dapat dilakukan dalam mengembangkan karakter anak usia dini adalah dengan memberikan penguatan (reinforcement) (Austin, 2016). Menurut Syafril (2018) penguatan adalah dampak dari kemungkinan suatu perilaku akan diulang atau tidak diulang oleh anak. Konsekuensi yang menyenangkan dari perilaku tertentu akan membuat seseorang cenderung mengulanginya.

Jenis penguatan ada dua yaitu penguatan positif dan negatif. Frieman (dalam Santrock, 2010) menjelaskan perbedaan mendasar antara penguatan positif dan penguatan negatif, yaitu dalam penguatan positif ada sesuatu yang ditambahkan atau diperoleh, sedangkan dalam penguatan negatif adanya sesuatu yang dikurangi atau dihilangkan. Penguatan positif dan penguatan negatif adalah setiap umpan balik yang guru berikan pada anak untuk merespon perilaku anak apakah perlu ditingkatkan atau dihilangkan. Penguatan dalam pembelajaran dapat diberikan secara verbal dan nonverbal (Amrullah, 2017; Saud, 2010). Secara umum, pemberian penguatan merupakan tindakan dan ucapan yang disengaja oleh guru untuk mengembangkan karakter anak.

Fenomena yang berkaitan dengan pengembangan karakter pada anak antara lain adalah maraknya kasus bullying pada anak di Indonesia. Selama rentang waktu 9 tahun dari 2011 sampai 2019, terdapat 2473 kasus bullying yang dilaporkan ke KPAI (KPAI, 2020). Sedangkan fenomena kasus bullying pada anak ini bagaikan gunung es, diduga masih banyak kasus yang tidak dilaporkan. Oleh karena itu, Pendidikan Anak Usia Dini (PAUD) adalah wadah yang sangat strategis untuk mengembangkan karakter anak. Taman Kanak-kanak (TK) adalah layanan PAUD pada jalur formal. Salah satu metode dalam peningkatan karakter di TK adalah melalui pembiasaan. Pelaksanaan pendidikan karakter di Indonesia sudah digaungkan sejak lama. Pada juknis pendidikan karakter, disebutkan bahwa salah satu nilai karakter yang penting ditanamkan sejak dini adalah tentang tanggung jawab. Adapun prinsip pendidikan karakter yang perlu dilaksanakan oleh guru PAUD ada tujuh, yaitu: (1) melalui keteladanan, (2) dilakukan berkelanjutan, (3) terintegrasi untuk semua aspek perkembangan, 
(4) dalam suasana penuh kasih sayang, (5) aktif memotivasi anak, (6) melibatkan semua unsur pendidik, dan (7) dilakukan asesmen penilaian (PAUD PNF, 2012).

Berkaitan dengan peningkatan karakter anak yang masih dalam masa tumbuh kembang, pendidik memang harus melakukan 'tarik ulur'. Pendidik atau guru diharapkan bersikap tidak terlalu keras pada anak karena hanya akan menimbulkan ketaatan semu dari anak. Sebaliknya juga bersikap tidak terlalu lembut karena anak akan menjadi acuh tak acuh dan tidak peduli (Angelina, 2020). Demikian pula, kekompakan unsur semua pendidik menjadi salah satu kunci penting dalam pengembangan karakter anak. Antara guru, orang tua dan masyarakat harus memiliki visi dan sikap yang sama dalam pengembangan karakter sehingga anak tidak mengalami kebingungan model karakter (Harrison, Tom; Morris, Ian; Ryan, 2016).

Salah satu masalah yang sering muncul pada peningkatan karakter di TK adalah karena adanya banyak faktor yang mempengaruhi tingkat keberhasilan dalam proses pembentukan tersebut. Diantaranya adalah faktor kebiasaan anak, baik di rumah maupun di lingkungan sekitarnya. Berdasarkan pengamatan peneliti di TK Dharma Wanita 1 Pojoksari Kecamatan Sukomoro Kabupaten Magetan, baru sekitar 8 dari 22 anak (36,4\%) yang sudah berkembang sangat baik dalam mengambil peralatan main tanpa dibantu. Begitu pula dalam bertanggung jawab untuk merapikan peralatan yang digunakan, baru ditunjukkan dengan konsisten oleh 9 dari 22 anak (40,9\%). Misalnya setiap hari anak-anak sudah diingatkan untuk membuang sampah pada tempatnya. Namun masih ada saja beberapa anak yang membuang sampah sembarangan. Begitu juga pada saat anak-anak selesai bermain, sangat jarang anakanak mau merapikan mainannya. Biasanya sebagian besar dari mereka pergi begitu saja setelah bermain. Tak jarang pendidik yang harus merapikan sendiri peralatan main setelah anak menggunakannya. Selain itu, beberapa anak cenderung tidak mau menyelesaikan tugas yang diberikan guru dengan berbagai alasan. Hanya 9 dari 22 anak $(40,9 \%)$ yang tercatat selalu menyelesaikan tugas tepat waktu sesuai arahan dari guru. Jika hal ini dibiarkan, maka anakanak tidak akan memiliki rasa bertanggung jawab. Hal ini dapat terjadi antara lain karena keluarga dan lingkungan tidak mampu menjadi model yang baik bagi anak.

Berdasarkan literatur, penguatan berupa kata-kata motivasi atau kalimat pujian pada anak akan dapat meningkatkan motivasi anak untuk mengulang perilaku yang diharapkan, sehingga akan meningkatkan karakternya (Syamsuarni \& Eliza, 2020). Pemberian hadiah dengan kriteria tertentu sebagai bentuk penguatan pada anak juga akan meningkatkan motivasinya untuk berperilaku baik seperti yang diharapkan lingkungannya (Kruse et al., 2020). Hasil penelitian Astuti (2019) menyatakan bahwa perilaku prososial anak berkembang melalui kegiatan outdoor learning berupa outbond, yang di dalamnya terdapat unsur reward berupa pengalaman langsung di alam. Sedangkan penelitian Rohayati (2018) menunjukkan bahwa sikap tanggung jawab anak meningkat melalui penguatan positif dalam metode proyek. Selain itu, hasil penelitian Verawati (2020) menunjukkan bahwa pemberian reward akan meningkatkan sikap disiplin anak. Jadi pemberian penguatan pada anak akan membantu anak untuk mengembangkan perilaku yang diharapkan. Anak-anak menjadi bersemangat dan tidak merasa terbebani untuk melakukannya. Dengan demikian peningkatan karakter diharapkan akan tercapai dengan optimal.

Untuk mencari solusi dari kasus tersebut maka peneliti menggunakan pemberian penguatan positif dalam meningkatkan karakter anak. Penguatan positif ini berbentuk verbal atau nonverbal. Secara verbal adalah dengan kata-kata afirmasi seperti bagus sekali, hebat. Penguatan non-verbal berupa acungan jempol, senyuman, dan pemberian hadiah. Oleh karena itu, tujuan penelitian ini adalah untuk meningkatkan karakter anak melalui pemberian penguatan pada anak kelompok B di TK Dharma Wanita 1 Pojoksari, Magetan, Indonesia.

\section{METODOLOGI}

Penelitian ini merupakan Penelitian Tindakan Kelas (PTK) yang dilakukan pada tahun 2020 dalam dua siklus. Penelitian dilakukan di TK Dharma Wanita 1 Pojoksari Kecamatan 
Sukomoro Kabupaten Magetan, dengan subjek penelitian 22 anak kelompok B, dengan rincian 12 anak laki-laki dan 10 anak perempuan. Teknik pengumpulan data yang digunakan adalah observasi dan dokumentasi. Tahap penelitian ini terdiri dari: perencanaan, pelaksanaan, pengamatan dan refleksi sesuai model penelitian Kemmis \& Taggart (Hayati, 2019).

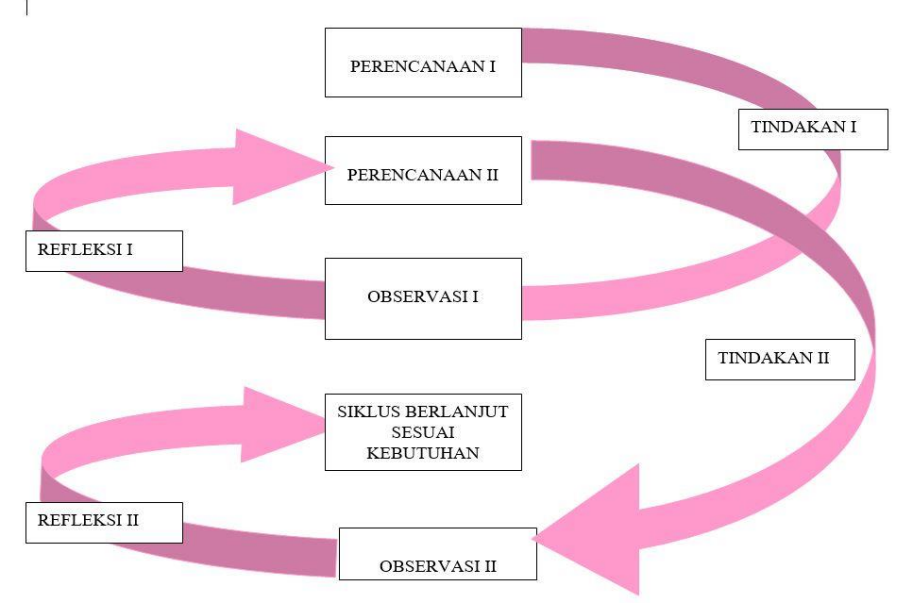

Gambar 1. Alur PTK Kemmis \& Taggart

Peningkatan karakter pada anak dibatasi dengan salah satu karakter utama yaitu 'bertanggung jawab', yang dilihat melalui 4 indikator utama yaitu: (1) mengambil peralatan main tanpa dibantu, (2) melakukan tugas dengan gembira, (3) menyelesaikan tugas yang diberikan dan (4) merapikan mainan setelah digunakan. Guru dibantu oleh satu orang guru pendamping untuk meyakinkan proses observasi dapat dilakukan dengan baik.

Indikator keberhasilan dalam penelitian ini yaitu setelah pelaksanaan penelitian anakanak dapat menunjukkan karakter yang positif dengan hasil minimal mencapai Kriteria Ketuntasan Minimum (KKM) yaitu 70\%. Angka 70\% adalah angka rata-rata untuk seluruh anak di dalam kelas, yang didapatkan dari perbandingan antara jumlah anak yang sudah mencapai ketuntasan dengan seluruh jumlah anak yang terlibat dalam penelitian. Analisis data pada penelitian ini adalah dengan teknik deskriptif kualitatif berdasarkan persentase, yaitu persentase dari nilai keseluruhan yang didapatkan anak dibagi dengan skor maksimum dikalikan jumlah seluruh anak (Arikunto, 2010).

\section{HASIL DAN PEMBAHASAN}

Tahap Perencanaan. Sebelum tahap pelaksanaan, guru melakukan proses pengamatan terhadap performansi karakter anak usia 5-6 tahun dalam menunjukkan karakter bertanggung jawab yang dibatasi pada empat indikator di atas yaitu: (1) mengambil peralatan main tanpa dibantu, (2) melakukan tugas dengan gembira, (3) menyelesaikan tugas yang diberikan, dan (4) merapikan mainan setelah digunakan. Hasil dari pengamatan pada pra siklus dapat dilihat pada tabel 1.

Berdasarkan hasil pengamatan awal sesuai Tabel 1 tersebut, terlihat bahwa anak-anak yang sudah berkembang dengan sangat baik dalam semua aspek yang diamati tak lebih dari 7 anak atau 32\% dari keseluruhan. Hal ini menunjukkan perlunya dilakukan perbaikan pembelajaran agar tumbuh karakter bertanggung jawab yang lebih baik pada anak, dan salah satu upaya tersebut adalah melalui penelitian tindakan kelas. Berdasarkan data tersebut, guru dibantu oleh guru pendamping membuat perencanaan tindakan kelas untuk siklus I dan siklus II. Rencana pemberian penguatan pada anak tiap siklus dibuat dalam Tabel 2. Berdasarkan Tabel 2 tersebut selanjutnya dibuat Rencana Pelaksanaan Pembelajaran Harian $(\mathrm{RPPH})$ yang meliputi kegiatan pembukaan, inti dan penutup, dengan fokus pada pemberian penguatan sesuai tabel. 
Tabel 1. Hasil Pengamatan Pra Siklus

\begin{tabular}{|c|c|c|c|c|c|c|c|c|c|}
\hline \multirow{2}{*}{ No. } & \multirow{2}{*}{ Aspek } & \multicolumn{2}{|c|}{ BB } & \multicolumn{2}{|c|}{ MB } & \multicolumn{2}{|c|}{ BSH } & \multicolumn{2}{|c|}{ BSB } \\
\hline & & $\mathrm{N}$ & $\mathrm{P}$ & $\mathrm{N}$ & $\mathrm{P}$ & $\mathrm{N}$ & $\mathrm{P}$ & $\mathrm{N}$ & $\mathrm{P}$ \\
\hline 1. & $\begin{array}{l}\text { Mengambil peralatan } \\
\text { main tanpa dibantu }\end{array}$ & 2 & $9 \%$ & 8 & $36 \%$ & 4 & $18 \%$ & 8 & $36 \%$ \\
\hline 2. & $\begin{array}{l}\text { Melakukan tugas } \\
\text { dengan gembira }\end{array}$ & 2 & $9 \%$ & 9 & $41 \%$ & 4 & $18 \%$ & 7 & $32 \%$ \\
\hline 3. & $\begin{array}{l}\text { Menyelesaikan tugas } \\
\text { yang diberikan }\end{array}$ & 1 & $5 \%$ & 7 & $32 \%$ & 5 & $23 \%$ & 9 & $41 \%$ \\
\hline 4. & $\begin{array}{l}\text { Merapikan mainan } \\
\text { setelah digunakan }\end{array}$ & 1 & $5 \%$ & 9 & $41 \%$ & 3 & $14 \%$ & 9 & $41 \%$ \\
\hline
\end{tabular}

Tabel 2. Rencana Tindakan Pemberian Penguatan

\begin{tabular}{|c|c|c|c|c|}
\hline Siklus & Hari & Jenis Penguatan & Kegiatan & Sentra \\
\hline \multirow[t]{5}{*}{ I } & 1. & $\begin{array}{l}\text { Pujian ketika anak mau } \\
\text { melakukan: }\end{array}$ & $\begin{array}{l}\text { Membuat bendera mainan, } \\
\text { membilang bendera, dan }\end{array}$ & $\begin{array}{l}\text { Sentra } \\
\text { persiapan }\end{array}$ \\
\hline & 2. & $\begin{array}{l}\text { a. Mengambil } \\
\text { peralatan main } \\
\text { tanpa dibantu }\end{array}$ & $\begin{array}{l}\text { membedakan perilaku baik dan buruk } \\
\text { Menggambar bentuk geometri, } \\
\text { bermain lego, dan bermain balok }\end{array}$ & $\begin{array}{l}\text { Sentra } \\
\text { pembangunan }\end{array}$ \\
\hline & 3. & $\begin{array}{l}\text { b. Melakukan tugas } \\
\text { dengan gembira }\end{array}$ & $\begin{array}{l}\text { Bermain pasir, bermain air, dan } \\
\text { meniru bentuk huruf dengan batu } \\
\text { kerikil }\end{array}$ & $\begin{array}{l}\text { Sentra bahan } \\
\text { alam }\end{array}$ \\
\hline & 4. & $\begin{array}{l}\text { c. Menyelesaikan tugas } \\
\text { yang diberikan }\end{array}$ & Bermain “Pergi ke Dokter' & Sentra main \\
\hline & 5. & $\begin{array}{l}\text { d. Merapikan mainan } \\
\text { setelah digunakan }\end{array}$ & $\begin{array}{l}\text { Praktek berwudhu, sholat, dan } \\
\text { merapikan perlengkapan sholat }\end{array}$ & $\begin{array}{l}\text { peran } \\
\text { Sentra imtaq }\end{array}$ \\
\hline \multirow[t]{5}{*}{ II } & 1. & $\begin{array}{l}\text { Memberikan pujian } \\
\text { dan hadiah bentuk } \\
\text { lencana bintang pada }\end{array}$ & $\begin{array}{l}\text { Membuat istana negara dengan } \\
\text { melipat, membilang gambar bus, dan } \\
\text { membedakan perilaku baik dan buruk }\end{array}$ & $\begin{array}{l}\text { Sentra } \\
\text { persiapan }\end{array}$ \\
\hline & 2 & $\begin{array}{l}\text { anak yang: } \\
\text { a. Mengambil }\end{array}$ & $\begin{array}{l}\text { Menggambar Tugu Monas, bermain } \\
\text { leggo, dan bermain balok }\end{array}$ & $\begin{array}{l}\text { Sentra } \\
\text { pembangunan }\end{array}$ \\
\hline & 3. & $\begin{array}{l}\text { peralatan main } \\
\text { tanpa dibantu }\end{array}$ & $\begin{array}{l}\text { Bermain pasir, bermain air, dan } \\
\text { meniru bentuk huruf dengan batu }\end{array}$ & $\begin{array}{l}\text { Sentra bahan } \\
\text { alam }\end{array}$ \\
\hline & 4. & $\begin{array}{l}\text { b. Melakukan tugas } \\
\text { dengan gembira }\end{array}$ & $\begin{array}{l}\text { kerikil } \\
\text { Bermain "Naik Kereta Api” }\end{array}$ & Sentra main \\
\hline & 5. & $\begin{array}{l}\text { c. Menyelesaikan tugas } \\
\text { yang diberikan } \\
\text { d. Merapikan mainan } \\
\text { setelah digunakan }\end{array}$ & $\begin{array}{l}\text { Praktek wudhu, sholat, dan } \\
\text { merapikan perlengkapan sholat }\end{array}$ & $\begin{array}{l}\text { peran } \\
\text { Sentra imtaq }\end{array}$ \\
\hline
\end{tabular}

Tahap Pelaksanaan. Siklus I dan Siklus II dilaksanakan masing-masing selama lima kali pertemuan. Pelaksanaan siklus I menggunaan tema Tanah Air dan sub tema Bendera Indonesia. Pada pertemuan pertama siklus I, guru mengajak anak membuat mainan bendera dengan teknik 3M (mewarnai, menggunting, menempel); menghitung jumlah bendera dan anak hormat pada bendera; dan membedakan perilaku baik dan buruk dengan memberi tanda $(\sqrt{ })$ dan $(X)$. Pada saat guru meminta anak mengambil peralatan dari loker masing-masing, Vi dan Ar justru memilih bermain balok. Setelah guru menghampiri mereka dan bertanya mengapa mereka tidak mengerjakan tugas seperti teman-temannya. Mereka menjawab, "Tidak mau". Saat anak-anak mengumpulkan tugas membilang bendera Na, Bh, dan Il masih duduk di kursi. Guru bertanya, ternyata mereka belum mampu menulis angka. Lalu guru memberi motivasi, "Kalian adalah anak-anak yang hebat dan pemberani, kalau tidak bisa, minta tolong ke Bu Guru ya", dan guru membimbing mereka membuat angka. Selesai kegiatan, anak-anak bermain bebas. $\mathrm{Na}, \mathrm{Bh}, \mathrm{Il}, \mathrm{Ri}$, dan Da segera ikut bermain balok bersama Vi dan Ar padahal peralatan mereka belum dikembalikan ke loker. Guru memberikan 
penguatan, "Yang mau membereskan peralatan adalah anak yang bertanggung jawab." Lalu mereka segera merapikan peralatannya, sehingga guru memberikan acungan dua jempol. Setelah bermain balok, Vi dan Ar tidak mau merapikan alat mainnya. Akhirnya balok dirapikan oleh $\mathrm{Na}$, Bh, Il, Da, dan Ri. “Hebat ya kalian...sudah menjadi anak yang bertanggung jawab," puji guru (CL01S01).

Pertemuan kedua Siklus I diisi dengan kegiatan: (1) bercakap-cakap tentang cara menjaga Bendera Merah Putih, (2) menggambar bentuk geometri $\mathrm{O}, \square, \Delta$, (3) bermain lego, dan (4) bermain balok. Saat kegiatan menggambar bentuk geometri, Vi dan Ar tidak mau mengambil peralatan dan tidak mau menggambar. Mereka memilih bermain lego dan balok. Selesai mengerjakan tugas, $\mathrm{Na}, \mathrm{Bh}$, Da dan Ri segera ikut bergabung bermain balok. Saat waktu bermain habis, mereka pergi begitu saja tanpa ada yang merapikan mainan. Guru mengingatkan, "Siapa yang mau membereskan mainan, dia adalah anak yang bertanggung jawab dan akan disayang Allah." Lalu mereka mau merapikan mainannya. Bu Guru memuji pada anak yang sudah mau merapikan mainan, "Hebat ya anak-anakku, karena sudah mau bertanggungjawab." Namun Vi dan Ar belum mau merapikan mainan (CL02S01).

Pertemuan ketiga Siklus I guru mengajak anak untuk: (1) mendengarkan cerita "Buku Kata Ajaib", (2) bertepuk tangan "Tepuk Bendera", (3) bermain pasir ajaib, (4) bermain air, dan (5) mbentuk huruf dengan cara menyusun dari batu kerikil. Pada saat diajak bermain air dan pasir, anak-anak segera menuju tempat bermain yang disediakan guru. Mereka sangat suka bermain air dan pasir. Terlihat Pu dan Ri berebut kaleng air. Guru mengingatkan salah satu aturan main yaitu bermain harus bergantian dan tidak berebut, "Bagi yang belum dapat bermain air dan pasir karena area ini sudah penuh, silahkan bermain meniru bentuk huruf dengan batu dahulu", kata Guru mengingatkan aturan main di sentra. Akhirnya anak-anak bermain tanpa berebut. Pada saat merapikan peralatan, terlihat $\mathrm{Na}, \mathrm{Da}, \mathrm{Vi}$, dan Ar asyik bermain papan luncur. Guru mengingatkan bahwa anak yang bertanggung jawab adalah yang mau merapikan mainannya. "Nanti kalau tidak mau beres-beres, tidak akan diajak bermain lagi". Setelah anak-anak merapikan mainan, guru berkata, "Terima kasih, kalian hebat ya sudah mau beres-beres dan bertanggung jawab" (CL03S01).

Pertemuan keempat Siklus I diisi dengan kegiatan: (1) bercakap-cakap tentang cita-cita dalam mengisi kemerdekaan, dan (2) bermain peran "Menjadi Dokter, Perawat, Pasien, Apoteker". Guru sudah menyiapkan peralatan anak-anak untuk bermain peran "Pergi ke Dokter". Guru membagi peran pada anak-anak: dokter (Am, We), perawat (Sa, Kh), apoteker (Sy, Au), dan pasien (anak-anak yang lain). Ketika anak-anak asyik bermain peran, Vi tidak mau ikut bermain dan memilih bermain lego kesukaannya. Ketika ditanya guru alasannya, dia menjawab tidak suka main dokter-dokteran. $\mathrm{Na}$, $\mathrm{Da}$, dan Ar yang menjadi pasien, ikut bermain lego bersama Vi hingga waktu habis. Tetapi saat selesai bermain, mereka pergi begitu saja. Guru memanggil mereka dan bertanya, "Siapa yang mau disayang Allah dan menjadi anak yang bertanggung jawab dengan mau merapikan mainan?" Setelah itu mereka mau merapikan mainan. Guru bertepuk tangan sambil berkata, "Selamat ya, kalian anak yang bertanggung jawab," (CL04S01).

Pada pertemuan kelima Siklus I, guru mengajak anak-anak untuk praktek berwudhu, praktek sholat, dan merapikan perlengkapan sholat. Setelah berbaris, anak-anak diajak praktek berwudhu lalu diajak praktek sholat. Ketika sholat, terlihat Vi dan Ar bercanda sehingga mengganggu konsentrasi anak yang lain. Guru segera mendekati mereka dan mengatakan dengan pelan, "Anak yang sholatnya sungguh-sungguh, akan mendapatkan pahala, disayang Allah dan dimasukkan ke dalam surga." Lalu mereka sholat dengan tertib. Selesai sholat Guru mengacungkan dua jempol pada anak-anak sambil berkata, " Anak-anak hebat semua, sholatnya tertib, terima kasih" (CL05S01).

Pelaksanaan siklus I dilanjutkan dengan siklus II karena belum mencapai kriteria keberhasilan penelitian. Selain dengan pujian dan kata-kata motivasi, pemberian penguatan pada siklus II juga dipadukan dengan pemberian hadiah pada anak berupa lencana bintang. Pelaksanaan Siklus II ini masih menggunakan tema tanah air namun dengan sub tema yang 
berbeda yaitu ibu kota negara. Pertemuan pertama siklus II diisi dengan kegiatan: (1) tanya jawab tentang nama Ibukota Negara Indonesia, (2) membuat bentuk istana negara dengan melipat, (3) membilang jumlah busway, dan (4) membedakan perilaku baik dan buruk dengan memberi tanda $(\sqrt{ })$ dan $(X)$. Setelah menjelaskan kegiatan yang perlu dilakukan hari itu, guru menjelaskan aturan main, yaitu: (1) anak harus mengambil peralatan sendiri, (2) jika tidak mampu mengambil peralatan sendiri, anak dapat minta tolong pada guru, (3) selesai bermain anak-anak diharapkan merapikan seua alat main, dan (4) anak yang sudah selesai dan merapikan alat mainannya akan mendapatkan hadiah dari guru. Anak-anak bertanya, "Hadiahnya apa Bu?" "Rahasia deh, " jawab guru. Semua anak terlihat antusias mengikuti kegiatan, namun Na dan Vi tidak mau melipat, alasannya tidak bisa. Lalu guru menawarkan bantuan, akhirnya mereka mau. Ketika waktunya merapikan mainan, $\mathrm{Na}$ dan $\mathrm{Vi}$ meninggalkan peralatannya di meja. Guru mengingatkan, jika mau merapikan akan mendapatkan hadiah. Akhirnya mereka mau, dan semua anak mendapatkan hadiah bentuk bintang yang disematkan di baju dan dibawa pulang. Guru berpesan bahwa bintangnya boleh dibawa pulang dan disimpan di rumah serta ditunjukkan kepada ayah ibu (CL01S02).

Pada pertemuan kedua Siklus II, guru mengajak anak-anak untuk: (1) bercakap-cakap tentang apa saja yang ada di ibu kota negara, (2) Menggambar "Tugu Monas", (3) bermain lego, dan (4) bermain balok. Pada hari itu guru merasa senang, karena ada beberapa anak yang datang dengan bangga memakai bintang hadiah kemarin. Sebelum kegiatan Bu Guru memotivasi jika anak-anak melaksanakan tugas dengan baik dan mau merapikan alat main selesai bermain, guru akan memberikan 2 bintang sekaligus. Akhirnya semua anak mengikuti kegiatan dengan baik. Selesai merapikan alat main, guru mempersilahkan anak-anak mengambil sendiri hadiahnya. Anak-anak tampak bangga memakainya. Guru berpesan bahwa hadiahnya boleh dibawa pulang untuk ditunjukkan kepada ayah ibu, besok silahkan dipakai lagi ke sekolah.

Pertemuan ketiga Siklus II diisi dengan kegiatan: (1) mendengarkan cerita "Seri Buku Kata Ajaib", (2) bertepuk tangan "Tepuk Indonesia", (3) bermain pasir ajaib, (4) bermain air, dan (5) meniru bentuk huruf dengan cara menyusun dari batu kerikil. Hari itu tampak berbeda karena semua anak datang dengan bangga memakai lencana bintang. Saat kegiatan inti, setelah guru menjelaskan aturan main guru berkata, "Jika anak-anak tidak bermain dengan tertib dan tidak mau merapikan mainan, maka bintang yang dipakai anak-anak akan diambil satu oleh bu guru." Akhirnya anak-anak bermain dengan tertib dan mau merapikan mainan karena tidak mau lencana bintangnya berkurang. Guru berkata, "Hari ini tidak ada yang diambil bintangnya karena semua anak sudah tertib bemain dan mau beres-beres. Hebat. Tepuk tangan untuk kita semua."

Pertemuan keempat Siklus II anak-anak diajak untuk bercakap-cakap tentang alat transportasi di Jakarta, dan bermain peran "Naik Kereta Api". Hari itu anak-anak datang ke TK dengan masih memakai lencana bintang di bajunya. Pada saat kegiatan inti, guru menjelaskan aturan main dan berkata ,"Jika hari ini anak-anak bermain dengan tertib dan mau beres-beres, Bu Guru akan menambah satu bintang lagi". Anak-anak bersorak gembira. Mereka bermain dengan tertib dan senang sekali memainkan peran sebagai masinis, penumpang, satpam dan petugas toilet. Saat selesai bermain dan diminta beres-beres, mereka sangat bersemangat sehingga semua anak mendapatkan 1 bintang lagi. Guru meminta anakanak menghitung jumlah bintang yang dipakainya. Guru berkata, "Jika anak-anak mau mendapat bintang lagi Hari Sabtu karena besok Jum'at libur, maka anak-anak harus menjadi anak yang bertanggung jawab. Caranya bagaimana?" Anak-anak menjawab, "Mau beresberes Bu Guru." Ibu Guru berkata, "Iya betul, jangan lupa jika bermain harus yang tertib. Oke?" Anak-anak menjawab serempak, “Oke Bu Guru“ (CL04S02).

Pada pertemuan kelima Siklus II, guru mengajak anak-anak untuk: (1) praktek berwudhu, (2) praktek sholat, dan (3) merapikan perlengkapan sholat. Anak-anak datang ke TK dengan memakai bintang. Setelah berbaris, anak-anak diajak berwudhu, lalu praktek sholat dhuha. Guru mengingatkan bagi yang sholat tertib dan mau merapikan peralatan 
sholat dengan rapi akan diberi 2 bintang sekaligus. Semua anak sholat dengan tertib dan mau merapikan mukena, sajadah, dan sarung masing-masing. Guru berkata, "Wah, anak-anak hebat ya sudah menjadi anak-anak yang sholeh dan sholehah, sholatnya tertib, dan bertanggung jawab." Lalu guru mengacungkan dua jempol dan membagikan 2 bintang sekaligus kepada anak-anak secara bergantian. "Coba sekarang dihitung, berapa jumlah bintang yang dimilik ianak-anak?" tanya guru. "Enam Bu Guru", jawab anak-anak." "Wah....banyak ya. Mulai hari Senin, silahkan simpan bintangnya di rumah, karena hadiahnya akan diganti dengan bentuk yang lain, yang lebih menarik, " kata guru. "Hadiahnya apa Bu Guru?" tanya mereka. "Rahasia deh, " jawab guru sambil tersenyum. Lalu anak-anak berdoa dan pulang.

Pada akhir siklus II anak-anak sudah menunjukkan karakter bertanggung jawab sesuai hasil pengamatan guru dan sudah memenuhi kriteria keberhasilan sehingga tidak dilanjutkan ke Siklus III.

Tahap Pengamatan. Tahap ini dilakukan sejalan dengan tahap pelaksanaan, karena yang diamati adalah tentang karakter jadi berfokus pada proses. Pelaksanaan pengamatan selain dilakukan oleh peneliti juga dibantu oleh guru pendamping.

Hasil pengamatan performa karakter tanggung jawab anak selama siklus I dapat dilihat pada Tabel 3 .

Tabel 3. Performansi karakter Anak Setelah Siklus I

\begin{tabular}{|c|c|c|c|c|c|c|c|c|c|}
\hline \multirow{2}{*}{ No. } & \multirow{2}{*}{ Aspek } & \multicolumn{2}{|c|}{$\mathrm{BB}$} & \multicolumn{2}{|c|}{$\mathrm{MB}$} & \multicolumn{2}{|c|}{$\mathrm{BSH}$} & \multicolumn{2}{|c|}{ BSB } \\
\hline & & $\mathrm{N}$ & $\mathrm{P}$ & $\mathrm{N}$ & $\mathrm{P}$ & $\mathrm{N}$ & $\mathrm{P}$ & $\mathrm{N}$ & $\mathrm{P}$ \\
\hline 1. & $\begin{array}{l}\text { Mengambil peralatan main tanpa } \\
\text { dibantu }\end{array}$ & 1 & $4,5 \%$ & 2 & $9,1 \%$ & 6 & $27,3 \%$ & 13 & $59,1 \%$ \\
\hline 2. & Melakukan tugas dengan gembira & 2 & $9,1 \%$ & 1 & $4,5 \%$ & 7 & $31,8 \%$ & 12 & $54,5 \%$ \\
\hline 3. & Menyelesaikan tugas yang diberikan & 1 & $4,5 \%$ & 3 & $13,6 \%$ & 7 & $31,8 \%$ & 11 & $50,0 \%$ \\
\hline 4. & Merapikan mainan setelah digunakan & 1 & $4,5 \%$ & 4 & $18,2 \%$ & 3 & $13,6 \%$ & 14 & $63,6 \%$ \\
\hline
\end{tabular}

Berdasarkan Tabel 3 tersebut terlihat bahwa aspek yang meningkat cukup baik adalah dalam merapikan mainan setelah digunakan. Secara umum terlihat bahwa perilaku bertanggung jawab anak sudah berkembang sangat baik baru dicapai 11 hingga 14 anak atau $50 \%$ hingga $63,6 \%$ dari keseluruhan. Hal ini belum sesuai kriteria keberhasilan penelitian dan masih memerlukan upaya perbaikan, sehingga dilanjutkan dengan perbaikan pada siklus II. Hasil pengamatan performansi karakter anak pada akhir siklus II dapat dilihat di Tabel 4.

Tabel 4. Performansi karakter Anak Setelah Siklus II

\begin{tabular}{|c|c|c|c|c|c|c|c|c|c|}
\hline \multirow{2}{*}{ No. } & \multirow{2}{*}{ Aspek } & \multicolumn{2}{|c|}{ BB } & \multicolumn{2}{|c|}{$\mathrm{MB}$} & \multicolumn{2}{|c|}{$\mathrm{BSH}$} & \multicolumn{2}{|c|}{ BSB } \\
\hline & & $\mathrm{N}$ & $\mathrm{P}$ & $\mathrm{N}$ & $\mathrm{P}$ & $\mathrm{N}$ & $\mathrm{P}$ & $\mathrm{N}$ & $\mathrm{P}$ \\
\hline 1. & $\begin{array}{l}\text { Mengambil peralatan main tanpa } \\
\text { dibantu }\end{array}$ & 0 & 0 & 0 & $0,0 \%$ & 1 & $4,5 \%$ & 21 & $95,5 \%$ \\
\hline 2. & Melakukan tugas dengan gembira & 0 & 0 & 1 & $4,5 \%$ & 1 & $4,5 \%$ & 20 & $90,9 \%$ \\
\hline 3. & Menyelesaikan tugas yang diberikan & 0 & 0 & 1 & $4,5 \%$ & 0 & $0,0 \%$ & 20 & $90,9 \%$ \\
\hline 4. & Merapikan mainan setelah digunakan & 0 & 0 & 1 & $4,5 \%$ & 0 & $0,0 \%$ & 21 & $95,5 \%$ \\
\hline
\end{tabular}

Berdasarkan Tabel 4 terlihat bahwa pada semua aspek terjadi peningkatan dan hampir konsisten pada skala 4 yang artinya berkembang sangat baik. Jika dilihat dari rata-rata capaian dari siklus I ke siklus II maka dapat dilihat grafik 1. Berdasarkan Grafik 1 terlihat bahwa untuk empat aspek yang diamati, 20 hingga 21 anak atau 90,9\% hingga 95,5\% sudah berkembang sangat baik. Hal ini sudah sesuai dengan kriteria keberhasilan penelitian sehingga penelitian tindakan kelas ini dihentikan hanya sampai Siklus II. 


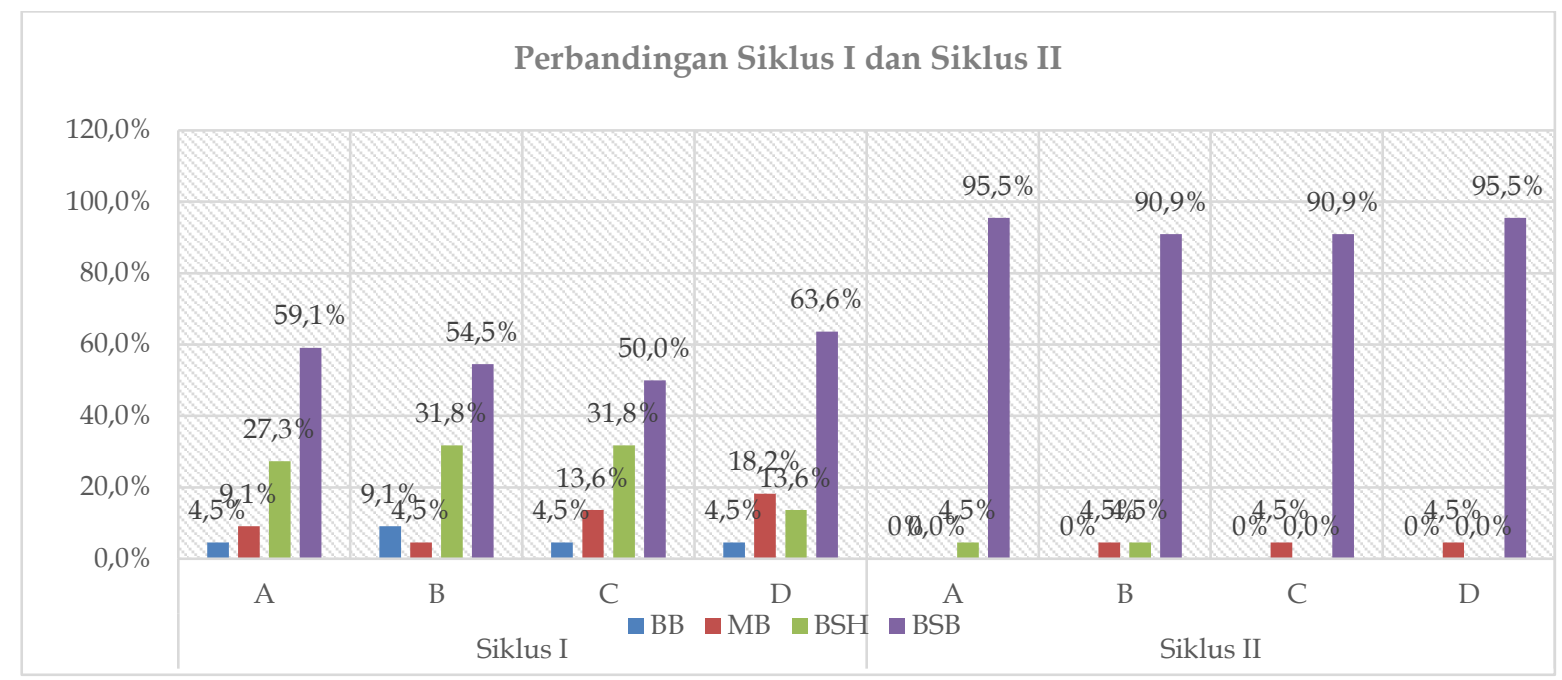

Grafik 1. Perbandingan SiklusI dengan Siklus II

Tahap Refleksi. Tahap refleksi dilakukan pada setiap akhir siklus. Hasil refleksi tersebut kemudian digunakan untuk memperbaiki rencana pembelajaran dalam meningkatkan karakter anak melalui penguatan. Hasil refleksi selama siklus I dapat dilihat pada Tabel 5.

Tabel 5. Refleksi Hasil Siklus 1

\begin{tabular}{lll}
\hline No. & Hal & \multicolumn{1}{c}{ Hasil Refleksi } \\
\hline 1. & $\begin{array}{l}\text { Reaksi anak terhadap } \\
\text { proses perbaikan }\end{array}$ & $\begin{array}{l}\text { Sebagian anak termotivasi dan mau merapikan mainan setelah } \\
\text { bermain }\end{array}$ \\
2. & $\begin{array}{l}\text { Kelemahan } \\
\text { Pemberian penghargaan berupa pujian kurang memotivasi sebagian } \\
\text { anak }\end{array}$ & $\begin{array}{l}\text { Pemberian penghargaan berupa pujian dapat memotivasi sebagian } \\
\text { besar anak agar memiliki perilaku bertanggung jawab }\end{array}$ \\
3. & Kelebihan & $\begin{array}{l}\text { Ada anak yang tidak peduli dan kurang berubah perilakunya dalam } \\
\text { bertanggung jawab meskipun sudah diberi pujian } \\
\text { Tidak hanya memberikan pujian ketika anak berperilaku } \\
\text { bertanggung jawab, tapi juga memberikan upaya penguatan lain, } \\
\text { misalnya hadiah bentuk bintang. }\end{array}$ \\
5. & Hal-hal unik & Upaya perbaikan \\
\hline
\end{tabular}

Oleh karena belum mencapai kriteria keberhasilan, penelitian dilanjutkan ke Siklus II. Penelitian siklus II berfokus pada penguatan dengan memberikan hadiah berupa bentuk bintang, selain masih mempertahankan penguatan berupa kalimat pujian seperti pada siklus I. Adapun hasil refleksi pada akhir siklus II ada di tabel 6.

Berdasarkan data hasil pengamatan siklus I pada Tabel 3, terlihat bahwa persentase peningkatan perilaku bertanggung jawab paling tinggi baru $63,6 \%$ dan belum memenuhi kriteria ketuntasan belajar. Hal ini disebabkan karena teknik pemberian pujian yang digunakan oleh guru kemungkinan belum tepat. Berdasarkan refleksi guru, pemberian pujian yang belum tepat dapat terjadi karena: (1) pujian tidak dilakukan sesegera mungkin saat anak menunjukkan perilaku yang diharapkan (Marson, 2020) (2) pujian hanya sebatas lisan, kurang dilakukan dengan tulus oleh guru dan hal ini dirasakan oleh anak (Hedo \& Sudhana, 2014), (3) kalimat yang dipilih guru dalam memuji terlalu umum dan tidak fokus pada keberhasilan anak yang sudah dicapai anal (Widyastuti, 2018). Hal ini misalnya terjadi pada hari kedua, saat guru mengatakan 'Hebat ya anak-anakku, karena sudah mau bertanggung jawab'. Kata 'tanggung jawab' masih terlalu abstrak untuk dipahami anak-anak. Seharusnya dapat ditambahkan dengan perilaku kongkrit yang dilakukan anak, dan (4) Guru kurang konsisten dalam memuji, kadang memuji kadang terlupa tidak memberikan pujian (Suteja \& Riyadi, 
2019). Akibatnya ada sebagian anak yang belum termotivasi untuk berperilaku bertanggung jawab. Oleh karena itu penelitian dilanjutkan ke siklus I.

Tabel 6. Refleksi Hasil Siklus II

\begin{tabular}{|c|c|c|}
\hline No. & Hal & Hasil Refleksi \\
\hline 1. & Reaksi anak & $\begin{array}{l}\text { Anak sangat senang saat diberi hadiah bintang sehingga termotivasi untuk } \\
\text { berperilaku bertanggung jawab }\end{array}$ \\
\hline 2. & Kelemahan & $\begin{array}{l}\text { Guru harus segera memberi hadiah bintang setelah anak berperilaku } \\
\text { bertanggung jawab. Hal ini membuat guru merasa kesulitan jika dilakukan } \\
\text { seorang diri. }\end{array}$ \\
\hline 3. & Kelebihan & $\begin{array}{l}\text { Pemberian pujian dan hadiah bintang sekaligus sangat memotivasi anak } \\
\text { agar berperilaku bertanggung jawab }\end{array}$ \\
\hline 4. & Hal-hal unik & $\begin{array}{l}\text { Reaksi anak luar biasa, mereka sangat senang dan bersemangat dalam } \\
\text { berperilaku bertanggung jawab karena diberi hadiah bintang }\end{array}$ \\
\hline 5. & $\begin{array}{l}\text { Upaya } \\
\text { perbaikan }\end{array}$ & $\begin{array}{l}\text { Pemberian pujian dan hadiah terbukti memotivasi anak menjadi lebih } \\
\text { bertanggung jawab }\end{array}$ \\
\hline
\end{tabular}

Berkaitan dengan sebab yang ketiga yaitu pujian yang bersifat umum, penelitian Dweck yang melakukan eksperimen tentang memuji dengan cara yang berbeda menarik untuk dicermati. Kelompok pertama dipuji karena kecerdasannya secara umum, sedangkan kelompok kelompok kedua dipuji atas usaha kerasnya. Ternyata kelompok pertama menunjukkan bahwa mereka kurang tahan banting (struggle) dibanding kelompok kedua (Tuason, 2013).

Selain itu, pujian juga perlu diberikan pada porsi yang pas, tidak berlebihan. Penelitian Thomaes \& Brummelman (2018) menunjukkan bahwa anak yang terlalu sering dipuji dan disanjung-sanjung justru memiliki kecerdasan rata-rata atau di bawahnya, merasa selalu lebih baik dari orang lain, dan menjadi lebih agresif ketika mendapatkan penolakan dari lingkungannya.

Salah satu kelemahan yang dirasakan guru dalam memberikan penguatan berupa hadiah sebagaimana tabel di atas adalah karena guru harus memberikan hadiah sesegera mungkin ketika anak menunjukkan perilaku yang diharapkan. Pada kondisi guru harus menangani anak didik dalam satu kelas, hal ini memang merepotkan. Oleh karena itu guru pendamping pada tingkat PAUD memang sangat diperlukan agar semua anak di dalam kelas dapat terlayani dengan baik (Saripudin, 2019). Selain membantu pembelajaran di kelas, guru pendamping juga dapat membantu guru inti untuk pengelolaan anak yang bersifat individual.

Penguatan dalam bentuk nonverbal antara lain adalah memberikan hadiah, dan dalam penelitian ini hadiah berupa bentuk lencana bintang yang ditempelkan pada baju anak. Pemberian hadiah sebagai penguatan memiliki kriteria tertentu, antara lain: (1) diberikan segera saat anak menunjukkan perilaku yang diharapkan (Munthe, 2019), (2) hadiah berupa benda tidak diberikan dalam jangka waktu lama pada anak karena akan menimbulkan ketergantungan pada hadiah (Silawati, 2018; Thomson, Rachel; Berriman, Liam; Brag, 2018) (3) hadiah nonverbal yang sifatnya bahasa tubuh seperti pelukan, sentuhan, acungan jempol, dapat diberikan selamanya (Anggraini et al., 2019) dan sangat membantu proses tumbuh kembang anak (Fadhillah, 2019), dan (4) pemberian hadiah perlu disertai kalimat yang jelas pada anak perilaku mana yang layak mendapatkan hadiah (Pratiwi \& Novianti, 2020; Whinnett, 2012). Kriteria tersebut juga menjadi dasar dalam pemberian hadiah pada penelitian ini, selain masih memberikan penguatan berupa kalimat pujian. Melalui penguatan berupa hadiah bintang tersebut, anak-anak memiliki kebanggaan tersendiri dengan lencana bintang yang terpasang pada bajunya. Semakin banyak mendapatkan lencana bintang, anak akan semakin bangga. Munculnya rasa bangga itu akan meningkatkan motivasi bagi anak untuk melakukan perilaku yang diharapkan guru (Djonko-Moore, 2020). 
Secara umum, tujuan penguatan bukan untuk melatih anak berbuat baik jika ada pamrih, namun lebih pada pembelajaran bahwa perilaku positifnya mendapat dukungan dari lingkungannya (Abubakar, 2018; Sigler \& Aamidor, 2005). Melalui penguatan, anak dapat memiliki rekaman di dalam otaknya bahwa menunjukkan perilaku yang positif itu membahagiakan dan membuat dirinya merasa berharga (Amalia, 2018). Oleh karena itu, penguatan pada anak harus diberikan dengan kriteria tertentu seperti di atas.

Aspek karakter bertanggung jawab yang diamati pada penelitian ini memang hanya terdiri dari empat aspek. Hal ini menjadi salah satu keterbatasan dalam penelitian ini. Pemillihan hanya empat aspek tersebut dilakukan supaya guru dapat fokus dalam melakukan pengamatan.

\section{SIMPULAN}

Berdasarkan pembahasan di atas, maka dapat disimpulkan bahwa pemberian penguatan dalam bentuk pujian dan pemberian hadiah dapat meningkatkan karakter anak khususnya dalam perilaku bertanggung jawab. Berdasarkan hasil pengamatan pada akhir kegiatan penelitian, terlihat peningkatan performa karakter bertanggung jawab anak sebesar $93,2 \%$. Penguatan dari guru baik verbal maupun nonverbal akan meningkatkan rasa bangga dan motivasi pada anak sehingga perilaku yang mendapatkan penguatan cenderung akan diulang. Melalui penelitian ini diharapkan para guru PAUD dapat lebih kreatif mengembangkan berbagai jenis penguatan yang bermakna bagi anak terutama untuk meningkatkan afeksi anak, salah satunya dalam meningkatkan karakter anak.

\section{UCAPAN TERIMA KASIH}

Ucapan terima kasih kepada Fakultas Keguruan dan Ilmu Pendidikan (FKIP) Universitas Terbuka yang telah memberikan kesempatan pada Prodi PGPAUD FKIP UT untuk melakukan penelitian dalam rangka memajukan pembelajaran anak usia dini.

\section{DAFTAR PUSTAKA}

Abubakar, S. R. (2018). Mencegah Lebih Efektif dari pada Menangani (Kasus Bullying Pada Anak Usia Dini). Jurnal Smart Paud, 1(1), 1. https:// doi.org/10.36709/jspaud.v1i1.3514

Allemand, M., \& Hill, P. L. (2014). Gratitude From Early Adulthood to Old Age. Journal of Personality, 84(1), 21-35. https:// doi.org/10.1111/jopy.12134

Amalia, R. (2018). Intervensi terhadap Anak Usia Dini yang Mengalami Gangguan (ADHD) Melalui Pendekatan Kognitif Perilaku dan Alderian Play Therapy. Jurnal Obsesi : Jurnal Pendidikan Anak Usia Dini, 2(1), 27. https:/ / doi.org/10.31004/obsesi.v2i1.4

Amrullah, A. K. (2017). Implementasi Pembelajaran Berbasis Masalah untuk Melatihkan Kemampuan Berpikir Kreatif dan Penguasaan Konsep Siswa Kelas V Sekolah Dasar. Jurnal Review Pendidikan Dasar: Jurnal Kajian Pendidikan Dan Hasil Penelitian, 3(1), 378. https://doi.org/10.26740/jrpd.v3n1.p378-387

Angelina, R. (2020). Strategi Konseling Keluarga Bagi Anak yang Berhenti Sekolah Akibat Pola Asuh Acuh Tak Acuh. https:/ / doi.org/10.31219/osf.io/da83j

Anggraini, V., Yulsyofriend, Y., \& Yeni, I. (2019). Stimulasi Perkembangan Bahasa Anak Usia Dini Melalui Lagu Kreasi Minangkabau Pada Anak Usia Dini. Pedagogi : Jurnal Anak Usia Dini Dan Pendidikan Anak Usia Dini, 5(2), 73. https://doi.org/10.30651/pedagogi.v5i2.3377

Arikunto, S. (2010). Penelitian Tindakan Kelas. Bumi Aksara.

Astuti, R. D. (2019). Pengembangan Perangkat Pembelajaran Metode Outdoor Learning Untuk Mengembangkan Perilaku Sosial Anak Usia Dini. Pedagogi : Jurnal Anak Usia Dini Dan Pendidikan Anak Usia Dini, 5(2), 20. https://doi.org/10.30651/ pedagogi.v5i2.3378

Austin, J. H. (2016). Developing Traits of Character on the Way to Altruism. In Living Zen Remindfully.

The

$\{\mathrm{MIT}\}$

Press. 
https:// doi.org/10.7551/mitpress/9780262035088.003.0003

Bachri, S., \& Suharnan, S. (2014). Kecerdasan Emosi, Persepsi terhadap Pendidikan Karakter Cinta Damai dan Penyesuaian Diri Remaja. Persona:Jurnal Psikologi Indonesia, 3(01). https:/ / doi.org/10.30996/ persona.v3i01.369

Djonko-Moore, C. M. (2020). Diversity education and early childhood teachers' motivation to remain in teaching: an exploration. Journal of Early Childhood Teacher Education, 1-19. https:/ / doi.org/10.1080/10901027.2020.1806151

Fadhillah, N. (2019). Pentingnya Pendidikan Anak Usia Dini Bagi Tumbuh Kembang Anak. https://doi.org/10.31219/osf.io/3j9qb

Harrison, Tom; Morris, Ian; Ryan, J. (2016). Teachers as Character Educators. In Teaching Character in the Primary Classroom (pp. 115-132). Learning Matters. https:// doi.org/10.4135/9781529714654.n9

Hayati, D. (2019). Proses Penerapan Etika Bertoilet pada Anak Usia Dini. Obsesi, 4(1), 316-325. https:// doi.org/https:// doi.org/10.31004/obsesi.v4i1.334

Hedo, D. J. P. K., \& Sudhana, H. (2014). Perbedaan agresivitas pada anak usia dini yang dibacakan dongeng dengan yang tidak dibacakan dongeng sebelum tidur oleh ibu. Jurnal Psikologi Udayana, 1(2). https:// doi.org/10.24843/jpu.2014.v01.i02.p01

Hidayat, O. S. (2019). Metode Pengembangan Moral dan Nilai-nilai Agama. Universitas Terbuka.

Istiana, I. (2018). Perbedaan Perilaku Prososial Remaja Ditinjau dari Jenis Kelamin di Kelurahan Tanjung Rejo Medan Sunggal. JURNAL DIVERSITA, 4(1), 58. https:// doi.org/10.31289/diversita.v4i1.1592

KPAI, T. (2020). Sejumlah Kasus Bullying Sudah Warnai Catatan Masalah Anak di Awal 2020, Begini Kata Komisioner KPAI. https://www.kpai.go.id/berita/sejumlah-kasus-bullyingsudah-warnai-catatan-masalah-anak-di-awal-2020-begini-kata-komisioner-kpai

Kruse, E., Faller, I., \& Read, K. (2020). Can Reading Personalized Storybooks to Children Increase Their Prosocial Behavior? Early Childhood Education Journal, 49(2), 273-282. https:// doi.org/10.1007/s10643-020-01069-x

Marson. (2020). Dampak saat Teduh Sebagai Implementasi Gaya Hidup Guru Sekolah Minuggu Terhadap Anak-anak Sekolah Minggu. https://doi.org/10.31219/osf.io/udbz8

Maslan, M. (2019). Hubungan Kompetensi Sosial Guru Kelas Terhadap Penanaman Pendidikan Karakter Siswa di Sekolah Dasar. JURNAL PAJAR (Pendidikan Dan Pengajaran), 3(6). https://doi.org/10.33578/ pjr.v3i6.8076

Megawangi, R. (2016). Pendidikan Karakter. Indonesia Heritage Foundation.

Megawati, E., \& Herdiyanto, Y. K. (2016). Hubungan antara Perilaku Prososial dengan Psychological Well-Being pada Remaja. Jurnal Psikologi Udayana, 3(1). https:/ / doi.org/10.24843/jpu.2016.v03.i01.p13

Mitsansw. (2014). Early childhood teachers' mental models of the environment. Korean Journal of Early Childhood Education, 34(1), 113-133. https:// doi.org/10.18023/kjece.2014.34.1.005

Munthe, S. R. (2019). Menunjukkan Perilaku Toleransi Terhadap Lingkungan di Rumah dan Sekolah. https:// doi.org/10.31227/osf.io/7tjkz

PAUD PNF, D. (2012). Pedoman Pendidikan Karakter pada Pendidikan Anak Usia Dini. http://paud.kemdikbud.go.id/wp-content/uploads/2016/03/juknispenyelenggaraan-pendidikan-karakter-file.pdf

Pratiwi, V. P., \& Novianti, R. (2020). Perilaku Anak Usia Dini Pecandu Lem Aibon Studi Kasus pada Anak Usia 5-6 Tahun di Desa Gumay Kecamatan Gelumbang. PERNIK: Jurnal Pendidikan Anak Usia Dini, 3(1). https:/ / doi.org/10.31851/pernik.v3i1.4192

Rohayati, E. (2018). Metode Pengembangan Keterampilan Bercerita yang Berkarakter untuk Pendidikan Anak Usia Dini. Cakrawala Dini: Jurnal Pendidikan Anak Usia Dini, 3(1). https:/ / doi.org/10.17509/cd.v3i1.10320

Santrock, J. W. (2010). Psikologi Pendidikan (Educational Psychologi, 2nd ed). Kencana Prenada Media Group. 
DOI: 10.31004/obsesi.v5i2.1128

Saptatiningsih, R. I., \& Permana, S. A. (2019). Early Childhood Character Building Troughtechnological Education. Journal of Physics: Conference Series, 1254, 12048. https://doi.org/10.1088/1742-6596/1254/1/012048

Saripudin, A. (2019). Kompetensi Guru Pendamping PAUD dalam Memenuhi Standar Layanan PAUD Non Formal di Kabupaten Tasikmalaya. AWLADY : Jurnal Pendidikan Anak, 5(2), 63. https:// doi.org/10.24235/awlady.v5i2.4848

Saud, U. S. (2010). Pengembangan Profesi Guru. Alfabeta.

Sigler, E. A., \& Aamidor, S. (2005). From Positive Reinforcement to Positive Behaviors: An Everyday Guide for the Practitioner. Early Childhood Education Journal, 32(4), 249-253. https://doi.org/10.1007/s10643-004-0753-9

Silawati, E. (2018). Stimulasi Guru pada Pembelajaran Bahasa Anak Usia Dini. Cakrawala Dini: Jurnal Pendidikan Anak Usia Dini, 3(2). https:/ / doi.org/10.17509/cd.v3i2.10334

Suteja, J., \& Riyadi, M. (2019). Revitalisasi Peran Orang Tua dan Guru dalam Memberikan Pendidikan Seks pada Anak. Equalita: Jurnal Pusat Studi Gender Dan Anak, 1(1), 38. https://doi.org/10.24235/equalita.v1i1.5154

Syafril, S. (2018). Silabus Psikologi Pendidikan- Pendidikan Anak Usia Dini (PIAUD). https://doi.org/10.31219/osf.io/ycba2

Syamsuarni, \& Eliza, D. (2020). The Development of Kato Nan Ampek Picture Storybook Models Through Literacy of Minangkabau Culture to Develop the Character During Early Childhood. Proceedings of the International Conference of Early Childhood Education (ICECE 2019). https:/ / doi.org/10.2991/assehr.k.200715.007

Thomaes, S., \& Brummelman, E. (2018). Parents' Socialization of Narcissism in Children. In Handbook of Trait Narcissism (pp. 143-148). Springer International Publishing. https://doi.org/10.1007/978-3-319-92171-6_15

Thomson, Rachel; Berriman, Liam; Brag, S. (2018). Everyday Childhoods: Time, Technology and Documentation. In Researching Everyday Childhoods: Time, Technology and Documentation in a Digital Age. Bloomsbury Academic. https:// doi.org/10.5040/9781350011779.ch-001

Tuason, M. T. G. (2013). Those who were born poor: A qualitative study of Philippine poverty. Qualitative Psychology, 1(S), 95-115. https://doi.org/10.1037/2326-3598.1.s.95

Verawati, I. (2020). Hubungan Pemberian Reward terhadap Perilaku Disiplin Anak Usia Dini. Jurnal Pendidikan Tambusai, 4(2), 1278-1287. https://doi.org/10.31004/jptam.v4i2.594

Whinnett, J. (2012). Gifts and Occupations: Froebels Gifts (Wooden Block Play) and Occupations (Construction and Workshop Experiences) Today. In Early Childhood Practice: Froebel Today (pp. 121-136). SAGE Publications Ltd. https://doi.org/10.4135/9781446251287.n11

Widyastuti, A. (2018). Bahasa Positif Guru Dalam Bimbingan dan Konseling Membentuk Karakter Positif Anak Usia Dini. Jurnal Fokus Konseling, 4(1), 107. https://doi.org/10.26638/jfk.525.2099 